\title{
On soil genesis in temperate humid climate. II. The behaviour of the non-clay fraction in some soil groups
}

\section{J. VAN SCHUYLENBORGH}

Department of Regional Pedology, Mineralogy and Geology, Agriculture University, Wageningen, Netherlands

\section{Summary}

The conclusions drawn in part $I$ of this series could be confirmed in all cases but one. This exception was discussed.

The final conclusion could be drawn that, although aluminium migrates with clay (if there is clay migration), the translocation of aluminium and iron is fundamentally caused by the same process.

\section{Introduction}

In part I of this investigation (VAN SCHUYLENBORGH, 1962) analytical data on the composition of the profiles of several soil groups were given; also the clay separates were analyzed. The results permitted certain conclusions on the genesis of the soils. One result was that in podzols, grey-brown podzolic-, brown podzolic-, and gley soils, the iron was more mobile than aluminium. In the acid brown earths, however, the reverse was true.

Because it is imaginable that the translocation of iron is a different process than that of aluminium (this can be transported by clay migration), it is necessary to investigate the non-clay fraction of the soil. It is not probable that this fraction moves by mechanical forces except perhaps the very fine part of the silt fraction. It is the purpose of this paper to study the translocations of iron and aluminium in the non-clay part of the soil.

\section{Methods}

The $\mathrm{SiO}_{2-}, \mathrm{Al}_{2} \mathrm{O}_{3-}$, and $\mathrm{Fe}_{2} \mathrm{O}_{3}$-contents of the non-clay fraction of the soils were calculated from the soil- and clay composition and the clay content. The results, with the silica sesquioxide ratios, are shown in the TABLE.

\section{Results and discussion}

The TABLE shows that the conclusions drawn in part $I$ of this publication series and recapitulated in the introduction, are comfirmed in all cases but one. This means that the translocation of iron and aluminium is fundamentally the same process.

Received for publication 12th October, 1962. 
ON SOIL GENESIS IN TEMPERATE HUMID CLIMATE. II. BEHAVIOUR OF THE NON-CLAY FRACTION

TABLE. Data on the non-clay fraction of various soil profiles; contents in percentages of oven-dry soil

\begin{tabular}{|c|c|c|c|c|c|c|c|c|c|}
\hline \multirow[t]{2}{*}{ Soil group } & \multirow[t]{2}{*}{ Profile } & \multirow[t]{2}{*}{ Horizon } & \multicolumn{3}{|c|}{ Percentages } & \multicolumn{4}{|c|}{ Molar ratios } \\
\hline & & & $\mathrm{SiO}_{2}$ & $\mathrm{Al}_{2} \mathrm{O}_{3}$ & $\mathrm{Fe}_{2} \mathrm{O}_{3}$ & $\begin{array}{l}\mathrm{SiO}_{2} / \\
\mathrm{R}_{2} \mathrm{O}_{3}\end{array}$ & $\begin{array}{l}\mathrm{SiO}_{2} / \\
\mathrm{Al}_{2} \mathrm{O}_{3}\end{array}$ & $\begin{array}{l}\mathrm{SiO}_{2} / \\
\mathrm{Fe}_{2} \mathrm{O}_{3}\end{array}$ & $\begin{array}{l}\mathrm{Al}_{2} \mathrm{O}_{3} \\
\mathrm{Fe}_{2} \mathrm{O}_{3}\end{array}$ \\
\hline \multirow[t]{3}{*}{$\begin{array}{l}\text { Podzol ..... } \\
\text { (Spodosol) }\end{array}$} & II & $\begin{array}{l}\mathbf{A}_{1} \\
\mathbf{A}_{2} \\
\mathbf{B}_{2 \mathrm{~h}} \\
\mathbf{B}_{2 \text { ir }} \\
\mathbf{C}\end{array}$ & $\begin{array}{l}84,9 \\
92,7 \\
83,2 \\
84,1 \\
85,7\end{array}$ & $\begin{array}{l}1,64 \\
2,00 \\
3,10 \\
4,56 \\
4,64\end{array}$ & $\begin{array}{l}0,41 \\
0,35 \\
1,40 \\
1,54 \\
1,19\end{array}$ & $\begin{array}{l}76 \\
71 \\
35 \\
26 \\
27\end{array}$ & $\begin{array}{l}88 \\
79 \\
46 \\
31 \\
31\end{array}$ & $\begin{array}{l}545 \\
702 \\
157 \\
141 \\
193\end{array}$ & $\begin{array}{l}6,18 \\
8,90 \\
3,46 \\
4,50 \\
6,15\end{array}$ \\
\hline & III & $\begin{array}{l}\mathbf{A}_{1} \\
\mathbf{A}_{2} \\
\mathbf{B}_{2 \mathrm{~h}} \\
\mathbf{B}_{2 \mathrm{ir}} \\
\mathbf{C}\end{array}$ & $\begin{array}{l}93,7 \\
96,4 \\
89,1 \\
90,7 \\
94,3\end{array}$ & $\begin{array}{l}0,96 \\
0,86 \\
2,24 \\
3,08 \\
2,32\end{array}$ & $\begin{array}{l}0,17 \\
0,10 \\
0,31 \\
0,88 \\
0,46\end{array}$ & $\begin{array}{r}133 \\
169 \\
62 \\
42 \\
61\end{array}$ & $\begin{array}{r}148 \\
191 \\
68 \\
50 \\
69\end{array}$ & $\begin{array}{r}1268 \\
2678 \\
782 \\
275 \\
542\end{array}$ & $\begin{array}{c}8,50 \\
14,0 \\
11,6 \\
5,49 \\
7,84\end{array}$ \\
\hline & IV & $\begin{array}{l}A_{1} \\
A_{2} \\
B_{2 h} \\
B_{2 i r} \\
C\end{array}$ & $\begin{array}{l}87,5 \\
89,3 \\
81,9 \\
83,6 \\
86,3\end{array}$ & $\begin{array}{l}0,97 \\
1,11 \\
1,95 \\
2,21 \\
1,20\end{array}$ & $\begin{array}{l}0,34 \\
0,32 \\
0,66 \\
0,74 \\
0,37\end{array}$ & $\begin{array}{r}126 \\
115 \\
59 \\
53 \\
102\end{array}$ & $\begin{array}{r}153 \\
136 \\
71 \\
64 \\
122\end{array}$ & $\begin{array}{l}694 \\
744 \\
333 \\
303 \\
625\end{array}$ & $\begin{array}{l}4,50 \\
5,45 \\
4,65 \\
4,72 \\
5,14\end{array}$ \\
\hline \multirow[t]{3}{*}{$\begin{array}{l}\text { Grey-brown podzolic } \\
\text { (Alfisol: Udalf) }\end{array}$} & VI & $\begin{array}{l}\mathbf{A}_{1} \\
\mathbf{A}_{2} \\
\mathbf{B}_{1} \\
\mathbf{B}_{2} \\
\mathbf{C}\end{array}$ & $\begin{array}{l}76,2 \\
78,7 \\
74,9 \\
66,3 \\
68,6\end{array}$ & $\begin{array}{l}2,48 \\
2,98 \\
3,00 \\
3,32 \\
3,42\end{array}$ & $\begin{array}{l}1,10 \\
1,22 \\
1,05 \\
0,97 \\
1,01\end{array}$ & $\begin{array}{l}41 \\
36 \\
35 \\
29 \\
29\end{array}$ & $\begin{array}{l}52 \\
45 \\
42 \\
34 \\
34\end{array}$ & $\begin{array}{l}181 \\
164 \\
189 \\
184 \\
190\end{array}$ & $\begin{array}{l}3,43 \\
3,63 \\
4,46 \\
5,43 \\
5,66\end{array}$ \\
\hline & VII & $\begin{array}{l}\mathbf{A}_{2} \\
\mathbf{B}_{1} \\
\mathbf{B}_{21} \\
\mathbf{B}_{\mathbf{2 2}}\end{array}$ & $\begin{array}{l}74,5 \\
72,7 \\
69,2 \\
68,4\end{array}$ & $\begin{array}{l}4,24 \\
4,70 \\
4,59 \\
4,98\end{array}$ & $\begin{array}{l}0,87 \\
1,37 \\
1,55 \\
1,97\end{array}$ & $\begin{array}{l}26 \\
22 \\
21 \\
19\end{array}$ & $\begin{array}{l}30 \\
26 \\
26 \\
23\end{array}$ & $\begin{array}{r}230 \\
141 \\
119 \\
89\end{array}$ & $\begin{array}{l}7,76 \\
5,36 \\
4,64 \\
3,81\end{array}$ \\
\hline & XV 1 & $\begin{array}{l}\mathbf{A}_{\mathrm{p}} \\
\mathbf{A}_{2} \\
\mathbf{B}_{1} \\
\mathbf{B}_{2}\end{array}$ & $\begin{array}{l}84,6 \\
84,9 \\
75,5 \\
62,7\end{array}$ & $\begin{array}{l}1,59 \\
1,48 \\
2,44 \\
3,99\end{array}$ & $\begin{array}{l}1,12 \\
0,83 \\
1,24 \\
2,72\end{array}$ & $\begin{array}{l}62 \\
72 \\
40 \\
19\end{array}$ & $\begin{array}{l}90 \\
98 \\
53 \\
27\end{array}$ & $\begin{array}{r}202 \\
272 \\
161 \\
62\end{array}$ & $\begin{array}{l}2,23 \\
2,79 \\
3,06 \\
2,30\end{array}$ \\
\hline $\begin{array}{l}\text { Brown podzolic } \ldots \\
\text { (Spodosol) }\end{array}$ & $\mathbf{x}$ & $\begin{array}{l}A_{1} \\
B_{2} \\
B_{3} \\
C\end{array}$ & $\begin{array}{l}83,6 \\
86,1 \\
87,3 \\
89,7\end{array}$ & $\begin{array}{l}1,92 \\
2,82 \\
3,17 \\
3,54\end{array}$ & $\begin{array}{l}0,85 \\
0,84 \\
0,96 \\
1,19\end{array}$ & $\begin{array}{l}58 \\
44 \\
39 \\
36\end{array}$ & $\begin{array}{l}74 \\
52 \\
47 \\
43\end{array}$ & $\begin{array}{l}263 \\
276 \\
243 \\
202\end{array}$ & $\begin{array}{l}3,54 \\
5,32 \\
5,18 \\
4,70\end{array}$ \\
\hline \multirow[t]{2}{*}{$\begin{array}{l}\text { Acid brown earth } \\
\text { (Inceptisol) }\end{array}$} & VIII & $\begin{array}{l}A_{1} \\
(B)_{1} \\
(B)_{3} \\
C\end{array}$ & $\begin{array}{l}86,6 \\
90,2 \\
90,0 \\
91,5\end{array}$ & $\begin{array}{l}1,60 \\
1,64 \\
1,92 \\
2,09\end{array}$ & $\begin{array}{l}0,57 \\
0,54 \\
0,57 \\
0,67\end{array}$ & $\begin{array}{l}75 \\
77 \\
67 \\
62\end{array}$ & $\begin{array}{l}92 \\
93 \\
80 \\
74\end{array}$ & $\begin{array}{l}401 \\
442 \\
417 \\
363\end{array}$ & $\begin{array}{l}4,36 \\
4,73 \\
5,23 \\
4,87\end{array}$ \\
\hline & IX & $\begin{array}{l}\mathrm{A}_{1} \\
(\mathrm{~B})_{1} \\
(\mathrm{~B})_{3} \\
\mathrm{C}\end{array}$ & $\begin{array}{l}82,4 \\
87,3 \\
90,5 \\
88,3\end{array}$ & $\begin{array}{l}2,48 \\
2,67 \\
3,73 \\
3,11\end{array}$ & $\begin{array}{l}1,28 \\
1,30 \\
1,33 \\
0,99\end{array}$ & $\begin{array}{l}42 \\
42 \\
34 \\
40\end{array}$ & $\begin{array}{l}40 \\
36 \\
41 \\
48\end{array}$ & $\begin{array}{l}172 \\
180 \\
182 \\
237\end{array}$ & $\begin{array}{l}3,04 \\
3,24 \\
4,41 \\
4,92\end{array}$ \\
\hline \multirow[t]{2}{*}{$\begin{array}{l}\text { Gley soil } \ldots \ldots \ldots \ldots \\
\text { (Alfisol: Aqualf) }\end{array}$} & $\mathbf{X I}$ & $\begin{array}{l}A_{1} \\
A_{28} \\
B_{18} \\
B_{28}\end{array}$ & $\begin{array}{l}76,8 \\
79,4 \\
72,0 \\
61,2\end{array}$ & $\begin{array}{l}5,14 \\
5,65 \\
6,82 \\
5,87\end{array}$ & $\begin{array}{l}1,73 \\
2,23 \\
3,60 \\
3,24\end{array}$ & $\begin{array}{l}21 \\
19 \\
13 \\
13\end{array}$ & $\begin{array}{l}25 \\
24 \\
18 \\
18\end{array}$ & $\begin{array}{r}119 \\
95 \\
53 \\
51\end{array}$ & $\begin{array}{l}4,67 \\
4,00 \\
2,97 \\
2,85\end{array}$ \\
\hline & XIV & $\begin{array}{l}A_{1} \\
A_{28} \\
B_{18} \\
B_{28} \\
G\end{array}$ & $\begin{array}{l}68,9 \\
72,3 \\
71,7 \\
63,8 \\
72,8\end{array}$ & $\begin{array}{l}4,17 \\
4,17 \\
4,60 \\
5,54 \\
5,47\end{array}$ & $\begin{array}{l}0,82 \\
1,13 \\
1,27 \\
1,44 \\
1,48\end{array}$ & $\begin{array}{l}25 \\
25 \\
23 \\
17 \\
19\end{array}$ & $\begin{array}{l}28 \\
29 \\
27 \\
20 \\
23\end{array}$ & $\begin{array}{l}230 \\
172 \\
149 \\
118 \\
135\end{array}$ & $\begin{array}{l}8,20 \\
5,71 \\
5,62 \\
6,03 \\
6,00\end{array}$ \\
\hline
\end{tabular}

1 Prof. XV was not included in Part I of this paper-series; it is an intergrade between a grey-brown and red-yellow podzolic soil in river loam. 
Although aluminium migrates with the clay minerals, if there is clay eluviation, the weathering reactions resulting in the liberation of $\mathrm{Al}_{2} \mathrm{O}_{3}$ and $\mathrm{Fe}_{2} \mathrm{O}_{3}$ and the subsequent translocation by organic acids, are more important.

The one exception is profile VI, being a grey-brown podzolic soil developed in loess. The non-clay fraction shows a more or less constant $\mathrm{Fe}_{2} \mathrm{O}_{3}$-content (see also the $\mathrm{SiO}_{2} / \mathrm{Fe}_{2} \mathrm{O}_{3}$-ratio), whereas the $\mathrm{Al}_{2} \mathrm{O}_{3}$-content of the different horizons definitely increases with depth. The clay fraction (see part I) shows just the reverse. This is difficult to understand. Apparently, the Al-silicates of the clay fraction are stable under the conditions of formation and the Al-minerals of the non-clay fraction are not. For the iron compounds in both fractions the reverse must then be true. The mineralogical examination of the sand fraction did not give sufficient support for this in so far that the percentage opaque minerals (for the greatest part magnetite) plus limonite is $55,74,35,44$ and 49 of the heavy fraction for the $A_{1}, A_{2}, B_{1}$ and $C$ respectively, which is fairly well in agreement with the $\mathrm{Fe}_{2} \mathrm{O}_{3}$-contents of the nonclay fraction. When we suppose that these minerals are stable under the formation conditions, this would account for the immobility of iron in the sandfraction.

Another possibility would be the migration of the very fine part of the silt fraction. This is, however, not very likely because the percentage silt decreases with depth, viz. 74,$0 ; 77,3 ; 74,7 ; 70,5$ and 72,2 in the $A_{1}, A_{2}, B_{1}, B_{2}$ and C-horizon respectively.

The profiles XI and XIV being developed in loess also, do not show such phenomena, probably because of the quite different soil forming conditions. Here the alternating reduction oxidation conditions in cooperation with the organic acids account for the translocation of iron.

\section{ACKNOWLEDGEMENTS}

This investigation was made possible by a grant of the Netherlands Organization for Pure Research (Z.W.O.).

The author wishes to thank Mr: L. Th. BegheYN and Mr. P. HeEres for doing most of the analyses.

\section{I T ERAT URE}

SCHUYLENBORGH, J. VAN

1962 On soil genesis in temperate humid climate. I. Some soil groups in the Netherlands. Neth. J. agric. Sci. 10, 127-144. 